\title{
Limitations of A Measurement Tool to Assess Systematic Reviews (AMSTAR) and suggestions for improvement
}

\author{
Brittany U. Burda ${ }^{*}$, Haley K. Holmer ${ }^{2}$ and Susan L. Norris ${ }^{3}$
}

\begin{abstract}
A Measurement Tool to Assess Systematic Reviews (AMSTAR) is a commonly used tool to assess the quality of systematic reviews; however, modifications are needed to improve its usability, reliability, and validity. In this commentary, we summarize our experience and the experiences of others who have used AMSTAR and provide suggestions for its improvement. We propose that AMSTAR should modify a number of individual items and their instructions and responses to make them more congruent with an assessment of the methodologic quality of systematic reviews. We recommend adding new items and modifying existing items to assess the quality of the body of evidence and to address subgroup and sensitivity analyses. More detailed instructions are needed for scoring individual items across multiple reviewers, and we recommend that a total score should not be calculated. These suggestions need to be empirically tested prior to implementation.
\end{abstract}

Keywords: Systematic review, Quality assessment, Risk of bias

\section{Background}

A Measurement Tool to Assess Systematic Reviews (AMSTAR) is a commonly used tool to assess the methodologic quality of systematic reviews [1]. It has demonstrated satisfactory reliability and construct validity [2] for systematic reviews of randomized controlled trials of treatment interventions [3]. AMSTAR is widely used to assess the quality of systematic reviews, and some users state it is the most appropriate (and best) tool [4-6], while others have found it problematic [7-17] and therefore modified the tool $[7,11,15,18-30]$. In this commentary, we summarize our experience using AMSTAR along with the experiences of others, describe several key issues, and provide suggestions for improvement (Table 1).

\section{Main text}

The stated objective of AMSTAR is to assess the methodological quality of systematic reviews [1] which refers to whether the authors of a study (or presumably a

\footnotetext{
*Correspondence: brittany.u.burda@gmail.com

${ }^{1}$ Kaiser Permanente Center for Health Research, 3800 N. Interstate Ave,

Portland, OR 97227, USA

Full list of author information is available at the end of the article
}

systematic review) did the best that they could [31]. The items of AMSTAR, however, largely address quality of reporting (e.g., items 5 and 6) [32] and risk of bias [33] (e.g., items 8 and 9) rather than the methodological quality. Several items should be amended to be consistent with the stated objective.

AMSTAR encompasses most of the key constructs that are relevant to the assessment of the methodological quality of systematic reviews; however, one critical construct is missing as noted also by other investigators [9, 34-36]: an explicit and reproducible method for assessing the quality of the body of evidence for each important outcome (i.e., the confidence in the estimates of effect [37]). We suggest revising item 8 to focus on this construct, separating it from the assessment of the quality of individual studies (item 7) (Table 1). AMSTAR also lacks an item that assesses subgroup and sensitivity analyses [9, 36]. Subgroup analyses are important to decision-makers as treatment effects may differ across populations. Similarly, sensitivity analyses specified a priori help to assess the robustness of the review's findings [31]. Items related to subgroups and sensitivity analyses should be added (new item 12, Table 1). 
Table 1 Concerns regarding AMSTAR items, instructions, responses, and suggested revisions

\begin{tabular}{|c|c|c|c|c|c|c|c|}
\hline \multicolumn{2}{|l|}{ AMSTAR tool $^{a}$} & \multicolumn{3}{|l|}{ Issues } & \multicolumn{3}{|l|}{ Suggested revisions } \\
\hline Item & Instructions & Related to the item & $\begin{array}{l}\text { Related to the } \\
\text { instructions }\end{array}$ & $\begin{array}{l}\text { Related to } \\
\text { the responses }\end{array}$ & Item & Instructions & Responses \\
\hline $\begin{array}{l}\text { 1. Was an "a priori" } \\
\text { design provided? }\end{array}$ & $\begin{array}{l}\text { The research question } \\
\text { and inclusion criteria } \\
\text { should be established } \\
\text { before the conduct of } \\
\text { the review. } \\
\text { Note: Need to refer } \\
\text { to protocol, ethics } \\
\text { approval, or pre- } \\
\text { determined/a priori } \\
\text { published research } \\
\text { objectives to score "yes." }\end{array}$ & $\begin{array}{l}\text { The phrase "a priori } \\
\text { design" is unclear. }\end{array}$ & $\begin{array}{l}\text { Unless a protocol is } \\
\text { available or the authors } \\
\text { explicitly state that the } \\
\text { design was developed a } \\
\text { priori, a "yes" response is } \\
\text { not indicated; thus "cannot } \\
\text { answer" is likely the most } \\
\text { common response. Many } \\
\text { review authors state that } \\
\text { they developed the } \\
\text { research questions and } \\
\text { inclusion criteria prior to } \\
\text { executing the search; } \\
\text { however, according to the } \\
\text { instructions, a report of } \\
\text { such an approach would } \\
\text { still be "cannot answer" as } \\
\text { there is no reference to a } \\
\text { protocol, for example. }\end{array}$ & $\begin{array}{l}\text { "Not applicable" is } \\
\text { not an appropriate } \\
\text { response. }\end{array}$ & $\begin{array}{l}\text { Reword: Were the } \\
\text { review questions } \\
\text { and inclusion/ } \\
\text { exclusion criteria } \\
\text { clearly delineated } \\
\text { prior to executing } \\
\text { the search strategy? }\end{array}$ & $\begin{array}{l}\text { Reword: The review } \\
\text { questions and inclusion/ } \\
\text { exclusion criteria should } \\
\text { be established a priori as } \\
\text { evidenced by a published } \\
\text { protocol or an explicit } \\
\text { statement in the review. } \\
\text { Note: If the review refers } \\
\text { to a protocol, ethics } \\
\text { approval, or to } \\
\text { pre-determined research } \\
\text { questions and inclusion/ } \\
\text { exclusions criteria, } \\
\text { score "yes." }\end{array}$ & $\begin{array}{l}\text { Remove the } \\
\text { "not applicable" } \\
\text { response. }\end{array}$ \\
\hline $\begin{array}{l}\text { 2. Was there duplicate } \\
\text { study selection and } \\
\text { data extraction? }\end{array}$ & $\begin{array}{l}\text { There should be at } \\
\text { least two independent } \\
\text { data extractors and a } \\
\text { consensus procedure } \\
\text { for disagreements } \\
\text { should be in place. } \\
\text { Note: Two people do } \\
\text { study selection, two } \\
\text { people do data } \\
\text { extraction, consensus } \\
\text { process or one person } \\
\text { checks the other's work. }\end{array}$ & None. & $\begin{array}{l}\text { The main sentence relates } \\
\text { to extraction only, and the } \\
\text { "note" relates to the other } \\
\text { aspects of the question. } \\
\text { The "note" is not clearly } \\
\text { written; for example, does } \\
\text { the consensus process } \\
\text { apply to study selection } \\
\text { as well? }\end{array}$ & $\begin{array}{l}\text { "Not applicable" is } \\
\text { not an appropriate } \\
\text { response. }\end{array}$ & None. & $\begin{array}{l}\text { Reword: There should be } \\
\text { at least two independent } \\
\text { assessors for study } \\
\text { selection (i.e., title, abstract } \\
\text { and full-text screening). } \\
\text { There should be either } \\
\text { duplicate independent } \\
\text { data extraction or } \\
\text { verification of extracted } \\
\text { data by a second person. } \\
\text { A consensus process } \\
\text { should be used when } \\
\text { disagreements arise in } \\
\text { either study selection at } \\
\text { the full-text stage or in } \\
\text { data extraction.Note: If } \\
\text { two independent people } \\
\text { do study selection and } \\
\text { data extraction is verified, } \\
\text { with consensus used in } \\
\text { the event of disagreements, } \\
\text { then indicate "yes." }\end{array}$ & $\begin{array}{l}\text { Remove the } \\
\text { "not applicable" } \\
\text { response. }\end{array}$ \\
\hline $\begin{array}{l}\text { 3. Was a } \\
\text { comprehensive } \\
\text { literature search } \\
\text { performed? }\end{array}$ & $\begin{array}{l}\text { At least two electronic } \\
\text { sources should be } \\
\text { searched. The report } \\
\text { must include years and } \\
\text { databases used (e.g., } \\
\text { Central, EMBASE, and } \\
\text { MEDLINE). Key words }\end{array}$ & $\begin{array}{l}\text { This item should proceed } \\
\text { to the current item } 2 \text {. }\end{array}$ & $\begin{array}{l}\text { Additional clarity is } \\
\text { needed and inclusion } \\
\text { and exclusion criteria } \\
\text { related to language of } \\
\text { publication should be } \\
\text { explicitly addressed. }\end{array}$ & $\begin{array}{l}\text { "Not applicable" is } \\
\text { not an appropriate } \\
\text { response. }\end{array}$ & $\begin{array}{l}\text { Reorder: This item } \\
\text { should precede } \\
\text { current item } 2 \text {. }\end{array}$ & $\begin{array}{l}\text { Reword: At least two } \\
\text { bibliographic databases } \\
\text { should be searched. The } \\
\text { report must include years } \\
\text { and databases examined } \\
\text { (e.g., Central, EMBASE, and } \\
\text { MEDLINE). Key words and/ }\end{array}$ & $\begin{array}{l}\text { Remove the } \\
\text { "not applicable" } \\
\text { response. }\end{array}$ \\
\hline
\end{tabular}


Table 1 Concerns regarding AMSTAR items, instructions, responses, and suggested revisions (Continued)

\begin{tabular}{|c|c|c|c|c|c|c|c|}
\hline & $\begin{array}{l}\text { and/or MESH terms } \\
\text { must be stated and } \\
\text { where feasible the } \\
\text { search strategy should } \\
\text { be provided. All } \\
\text { searches should be } \\
\text { supplemented by } \\
\text { consulting current } \\
\text { contents, reviews, } \\
\text { textbooks, specialized } \\
\text { registers, or experts in } \\
\text { the particular field of } \\
\text { study, and by reviewing } \\
\text { the references in the } \\
\text { studies found. } \\
\text { Note: At least two } \\
\text { sources plus one } \\
\text { supplementary strategy } \\
\text { used, select "yes." }\end{array}$ & & & & & $\begin{array}{l}\text { or MESH terms must be } \\
\text { reported and the search } \\
\text { strategy available. All } \\
\text { searches should be } \\
\text { supplemented by } \\
\text { consulting reviews, } \\
\text { specialized registers, or } \\
\text { experts in the particular } \\
\text { field of study, and by } \\
\text { reviewing the references } \\
\text { in the studies found. } \\
\text { Publications in all relevant } \\
\text { languages should be } \\
\text { sought and a justification } \\
\text { provided when there are } \\
\text { language restrictions. } \\
\text { Note: If at least two } \\
\text { bibliographic databases } \\
\text { plus one supplementary } \\
\text { strategy were used, } \\
\text { select "yes." }\end{array}$ & \\
\hline $\begin{array}{l}\text { 4. Was the status } \\
\text { of publication (i.e. } \\
\text { gray literature) } \\
\text { used as an } \\
\text { inclusion criterion? }\end{array}$ & $\begin{array}{l}\text { The authors should } \\
\text { state that they searched } \\
\text { for reports regardless } \\
\text { of their publication } \\
\text { type. The authors } \\
\text { should state whether } \\
\text { or not they excluded } \\
\text { any reports (from the } \\
\text { systematic review), } \\
\text { based on their } \\
\text { publication status, } \\
\text { language, etc. } \\
\text { Note: If review indicates } \\
\text { that there was a search } \\
\text { for "gray literature" or } \\
\text { "unpublished literature," } \\
\text { indicate "yes." Single } \\
\text { database, dissertations, } \\
\text { conference proceedings, } \\
\text { and trial registries are all } \\
\text { considered gray for this } \\
\text { purpose. If searching a } \\
\text { source that contains } \\
\text { both gray and non-gray, } \\
\text { must specify that they } \\
\text { were searching for gray/ } \\
\text { unpublished literature. }\end{array}$ & $\begin{array}{l}\text { As written, this item is a } \\
\text { reporting issue and not } \\
\text { a quality issue. The item } \\
\text { implies that if publication } \\
\text { status was an inclusion } \\
\text { (or exclusion) criterion, } \\
\text { you respond "yes." This } \\
\text { differs from the } \\
\text { instructions which focus } \\
\text { on the appropriate } \\
\text { inclusion of gray literature. }\end{array}$ & $\begin{array}{l}\text { The second sentence } \\
\text { suggests that the review } \\
\text { simply has to state if any } \\
\text { reports were excluded } \\
\text { based on publication type, } \\
\text { which is a reporting issue } \\
\text { and not a quality issue. } \\
\text { Language of publication } \\
\text { is primarily an issue of } \\
\text { gray literature. }\end{array}$ & $\begin{array}{l}\text { "Not applicable" is } \\
\text { not an appropriate } \\
\text { response. }\end{array}$ & $\begin{array}{l}\text { Reword: Was } \\
\text { relevant gray } \\
\text { literature } \\
\text { included in the } \\
\text { review? } \\
\text { Reorder: This } \\
\text { item should } \\
\text { follow current } \\
\text { item } 3 \text {. }\end{array}$ & $\begin{array}{l}\text { Reword: The authors } \\
\text { searched for and } \\
\text { considered gray } \\
\text { literature (e.g., trial } \\
\text { registries, conference } \\
\text { abstracts, dissertations, } \\
\text { and unpublished } \\
\text { reports) as appropriate } \\
\text { to the research question. } \\
\text { Note: If the review } \\
\text { indicates that there } \\
\text { was a search for gray } \\
\text { literature that is } \\
\text { appropriate to the } \\
\text { research question, } \\
\text { score "yes." }\end{array}$ & $\begin{array}{l}\text { Remove the " } \\
\text { not applicable" } \\
\text { response. }\end{array}$ \\
\hline $\begin{array}{l}\text { 5. Was a list of } \\
\text { studies (included }\end{array}$ & $\begin{array}{l}\text { A list of included and } \\
\text { excluded studies should } \\
\text { be provided. }\end{array}$ & None. & $\begin{array}{l}\text { Including a list of all } \\
\text { excluded studies may not } \\
\text { be feasible, even if online }\end{array}$ & $\begin{array}{l}\text { "Not applicable" is } \\
\text { not an appropriate } \\
\text { response. }\end{array}$ & None. & $\begin{array}{l}\text { Reword: A list of included } \\
\text { and excluded studies at } \\
\text { the full-text stage should }\end{array}$ & $\begin{array}{l}\text { Remove the } \\
\text { "not applicable" } \\
\text { response. }\end{array}$ \\
\hline
\end{tabular}


Table 1 Concerns regarding AMSTAR items, instructions, responses, and suggested revisions (Continued)

\begin{tabular}{|c|c|c|c|c|c|c|c|}
\hline $\begin{array}{l}\text { and excluded) } \\
\text { provided? }\end{array}$ & $\begin{array}{l}\text { Note: Acceptable if the } \\
\text { excluded studies are } \\
\text { referenced. If there is an } \\
\text { electronic link to the list, } \\
\text { but the link is dead, } \\
\text { select "no." }\end{array}$ & & $\begin{array}{l}\text { capabilities are available. It } \\
\text { is unclear at what stage } \\
\text { the excluded list is } \\
\text { focused; the full-text or the } \\
\text { title and abstract stage. }\end{array}$ & & & $\begin{array}{l}\text { be available to the reader } \\
\text { (either within the } \\
\text { publication, in an online } \\
\text { appendix, or from the } \\
\text { review authors). } \\
\text { Note: If a list of both } \\
\text { included and excluded } \\
\text { studies (the latter at the } \\
\text { full-text stage) is } \\
\text { available either directly } \\
\text { or by inquiry, then } \\
\text { score "yes." }\end{array}$ & \\
\hline $\begin{array}{l}\text { 6. Were the } \\
\text { characteristics of } \\
\text { the included } \\
\text { studies provided? }\end{array}$ & $\begin{array}{l}\text { In an aggregated form } \\
\text { such as a table, data } \\
\text { from the original } \\
\text { studies should be } \\
\text { provided on the } \\
\text { participants, } \\
\text { interventions and } \\
\text { outcomes. The } \\
\text { ranges of } \\
\text { characteristics in } \\
\text { all the studies } \\
\text { analyzed e.g. age, } \\
\text { race, sex, relevant } \\
\text { socioeconomic data, } \\
\text { disease status, } \\
\text { duration, severity, } \\
\text { or other diseases } \\
\text { should be reported. } \\
\text { Note: Acceptable if } \\
\text { not in table format } \\
\text { as long as they are } \\
\text { described as above. }\end{array}$ & $\begin{array}{l}\text { As written, this question } \\
\text { focuses on reporting } \\
\text { and not quality. }\end{array}$ & $\begin{array}{l}\text { It should be emphasized } \\
\text { that the ranges of } \\
\text { characteristics should be } \\
\text { tailored to the review } \\
\text { question. }\end{array}$ & $\begin{array}{l}\text { "Not applicable" is } \\
\text { not an appropriate } \\
\text { response. }\end{array}$ & None. & $\begin{array}{l}\text { Reword: In summary } \\
\text { form, relevant data from } \\
\text { the individual studies } \\
\text { should be provided on } \\
\text { the participants, interventions, } \\
\text { comparators and outcomes. } \\
\text { Note: If the summary provides } \\
\text { the information necessary for } \\
\text { the reader to understand } \\
\text { the key characteristics of } \\
\text { each study, score "yes." }\end{array}$ & $\begin{array}{l}\text { Remove the } \\
\text { "not applicable" } \\
\text { response. }\end{array}$ \\
\hline $\begin{array}{l}\text { 7. Was the scientific } \\
\text { quality of the included } \\
\text { studies assessed and } \\
\text { documented? }\end{array}$ & $\begin{array}{l}\text { A priori methods of } \\
\text { assessment should be } \\
\text { provided (e.g., for } \\
\text { effectiveness studies if } \\
\text { the author(s) chose } \\
\text { to include only } \\
\text { randomized, double- } \\
\text { blind, placebo } \\
\text { controlled studies, or } \\
\text { allocation concealment } \\
\text { as inclusion criteria); for } \\
\text { other types of studies } \\
\text { alternative items will } \\
\text { be relevant. } \\
\text { Note: Can include use } \\
\text { of a quality scoring tool } \\
\text { or checklist (e.g., Jadad }\end{array}$ & $\begin{array}{l}\text { The meaning of "scientific } \\
\text { quality" is unclear. At the } \\
\text { individual study level, an } \\
\text { assessment of the risk of } \\
\text { bias is likely to be more } \\
\text { useful than consideration } \\
\text { of quality. It is also unclear } \\
\text { if this item refers to the } \\
\text { individual study or to the } \\
\text { body of evidence. }\end{array}$ & $\begin{array}{l}\text { The meaning of the phrase } \\
\text { a priori methods of } \\
\text { assessment" is unclear. The } \\
\text { tools used to assess risk of } \\
\text { bias should be reliable, } \\
\text { valid and tailored to the } \\
\text { study design and include } \\
\text { relevant contextual } \\
\text { issues. } \\
\text { Quality scoring tools } \\
\text { are not generally } \\
\text { recommended because } \\
\text { they require each item to } \\
\text { be weighted relative to } \\
\text { other items. } \\
\text { A sensitivity analysis is }\end{array}$ & $\begin{array}{l}\text { "Not applicable" is } \\
\text { not an appropriate } \\
\text { response. }\end{array}$ & $\begin{array}{l}\text { Reword: Was the } \\
\text { risk of bias assessed } \\
\text { for each included } \\
\text { study, taking } \\
\text { into account } \\
\text { important potential } \\
\text { confounders and } \\
\text { other sources of } \\
\text { bias relevant to } \\
\text { the review question? }\end{array}$ & $\begin{array}{l}\text { Reword: At least two authors } \\
\text { should assess the risk of bias } \\
\text { using an instrument } \\
\text { appropriate to the study } \\
\text { design and context. A } \\
\text { consensus process should } \\
\text { be used to determine the } \\
\text { final assessment. The risk } \\
\text { of bias should be reported } \\
\text { for each study. Quality } \\
\text { scores should not be used; } \\
\text { categories such as high, } \\
\text { moderate, and } \\
\text { low are preferred. } \\
\text { Note: If the risk of bias of } \\
\text { each included study was }\end{array}$ & $\begin{array}{l}\text { Remove the } \\
\text { "not applicable" } \\
\text { response. }\end{array}$ \\
\hline
\end{tabular}

tan appropriate

response.
Reword: In summary

Remove the

t applicable"

understand

ach included study was 
Table 1 Concerns regarding AMSTAR items, instructions, responses, and suggested revisions (Continued)

\begin{tabular}{|c|c|c|c|c|c|c|c|}
\hline & $\begin{array}{l}\text { scale, risk of bias, } \\
\text { sensitivity analysis, etc.), } \\
\text { or a description of } \\
\text { quality items with some } \\
\text { kind of result for each } \\
\text { study ("low" or "high" is } \\
\text { fine, as long as it is clear } \\
\text { which studies scored } \\
\text { "low" and which scored } \\
\text { "high"; a summary } \\
\text { score/range for all } \\
\text { studies is not } \\
\text { acceptable. }\end{array}$ & & $\begin{array}{l}\text { not a type of quality } \\
\text { tool or checklist. }\end{array}$ & & & $\begin{array}{l}\text { appropriately assessed } \\
\text { and reported, score "yes." }\end{array}$ & \\
\hline $\begin{array}{l}\text { 8. Was the scientific } \\
\text { quality of the } \\
\text { included studies } \\
\text { used appropriately } \\
\text { in formulating } \\
\text { conclusions? }\end{array}$ & $\begin{array}{l}\text { The results of the } \\
\text { methodological rigor } \\
\text { and scientific quality } \\
\text { should be considered } \\
\text { in the analysis and the } \\
\text { conclusions of the } \\
\text { review, and explicitly } \\
\text { stated in formulating } \\
\text { recommendations. } \\
\text { Note: Might say } \\
\text { something such as "the } \\
\text { results should be } \\
\text { interpreted with caution } \\
\text { due to poor quality of } \\
\text { included studies." } \\
\text { Cannot score "yes" for } \\
\text { question if scored "no" } \\
\text { for question } 7 .\end{array}$ & $\begin{array}{l}\text { The meaning of "scientific } \\
\text { quality" is unclear. }\end{array}$ & $\begin{array}{l}\text { Systematic reviews should } \\
\text { not contain } \\
\text { recommendations; the } \\
\text { difference between } \\
\text { methodological rigor and } \\
\text { scientific quality is unclear; } \\
\text { and additional guidance is } \\
\text { needed on how best to } \\
\text { use quality assessments } \\
\text { when formulating } \\
\text { conclusions. The item } \\
\text { refers only to conclusions; } \\
\text { however the instructions } \\
\text { refer to both analysis and } \\
\text { conclusions. It is unclear } \\
\text { how quality should be } \\
\text { considered in analyses. }\end{array}$ & $\begin{array}{l}\text { It is unclear how } \\
\text { the response "not } \\
\text { applicable" would } \\
\text { be applied. }\end{array}$ & $\begin{array}{l}\text { Reword: Was the } \\
\text { quality of the } \\
\text { body of evidence } \\
\text { appropriately } \\
\text { assessed and } \\
\text { considered in } \\
\text { formulating the } \\
\text { conclusions of } \\
\text { the review? }\end{array}$ & $\begin{array}{l}\text { Reword: The review } \\
\text { authors should have } \\
\text { assessed the quality } \\
\text { of the body of evidence } \\
\text { for each important } \\
\text { outcome across studies } \\
\text { using GRADE or } \\
\text { another explicit and } \\
\text { transparent approach } \\
{[37,60,61] \text {, and the }} \\
\text { review conclusions } \\
\text { should reflect that } \\
\text { assessment. } \\
\text { Note: Score "yes" if the } \\
\text { review authors appropriately } \\
\text { considered the quality of } \\
\text { the body of evidence } \\
\text { (across studies) for each } \\
\text { important and critical } \\
\text { outcome in the review's } \\
\text { conclusions. }\end{array}$ & $\begin{array}{l}\text { Remove the } \\
\text { "not applicable" } \\
\text { response. }\end{array}$ \\
\hline $\begin{array}{l}\text { 9. Were the methods } \\
\text { used to combine the } \\
\text { findings of studies } \\
\text { appropriate? }\end{array}$ & $\begin{array}{l}\text { For the pooled results, a } \\
\text { test should be done to } \\
\text { ensure the studies were } \\
\text { combinable, to assess } \\
\text { their homogeneity (i.e., } \\
\chi^{2} \text { test for homogeneity, } \\
\left.\mathcal{R}^{2}\right) \text {. If heterogeneity } \\
\text { exists a random effects } \\
\text { model should be used } \\
\text { and/or the clinical } \\
\text { appropriateness of } \\
\text { combining should be } \\
\text { taken into consideration } \\
\text { (i.e. is it sensible } \\
\text { to combine?). }\end{array}$ & $\begin{array}{l}\text { The item addresses the } \\
\text { method for combining } \\
\text { studies, yet the instructions } \\
\text { relate to issues of statistical } \\
\text { heterogeneity and imply } \\
\text { that a meta-analysis } \\
\text { was performed. }\end{array}$ & $\begin{array}{l}\text { It is not appropriate } \\
\text { to examine statistical } \\
\text { heterogeneity before } \\
\text { clinical appropriateness: } \\
\text { the latter should always } \\
\text { be performed first. Tests } \\
\text { for heterogeneity do not } \\
\text { "ensure the studies were } \\
\text { combinable." }\end{array}$ & None. & $\begin{array}{l}\text { Reword: Were the } \\
\text { data appropriately } \\
\text { synthesized in a } \\
\text { qualitative manner } \\
\text { and if applicable, } \\
\text { was heterogeneity } \\
\text { assessed? If a } \\
\text { meta-analysis was } \\
\text { performed, was } \\
\text { it appropriate? }\end{array}$ & $\begin{array}{l}\text { Reword: Authors should } \\
\text { provide a qualitative } \\
\text { synthesis and explore } \\
\text { heterogeneity if applicable. } \\
\text { If a meta-analysis was } \\
\text { performed, it should have } \\
\text { been performed in an } \\
\text { appropriate manner. } \\
\text { Note: Score "yes" if the } \\
\text { qualitative synthesis is } \\
\text { appropriate, if heterogeneity } \\
\text { was explored, and if a } \\
\text { meta-analysis was } \\
\text { performed, it was appropriate. }\end{array}$ & None. \\
\hline
\end{tabular}

Note: Indicate "yes" 
Table 1 Concerns regarding AMSTAR items, instructions, responses, and suggested revisions (Continued)

\begin{tabular}{|c|c|c|c|c|c|c|c|}
\hline & $\begin{array}{l}\text { describe heterogeneity } \\
\text { (i.e., if they explain but } \\
\text { cannot pool because of } \\
\text { heterogeneity/variability } \\
\text { between interventions. }\end{array}$ & & & & & & \\
\hline $\begin{array}{l}\text { 10. Was the likelihood } \\
\text { of publication bias } \\
\text { assessed? }\end{array}$ & $\begin{array}{l}\text { An assessment of } \\
\text { publication bias should } \\
\text { include a combination } \\
\text { of graphical aids (e.g., } \\
\text { funnel plot, other } \\
\text { available tests) and/or } \\
\text { statistical tests (e.g., } \\
\text { Egger regression } \\
\text { test).Note: If no test } \\
\text { values or funnel plots } \\
\text { included, score "no." } \\
\text { Score "yes" if mentions } \\
\text { that publication bias } \\
\text { could not be assessed } \\
\text { because there were } \\
\text { fewer than } 10 \text { included } \\
\text { studies. }\end{array}$ & None. & $\begin{array}{l}\text { These tests examine the } \\
\text { issue of small study bias, } \\
\text { not publication bias per se. } \\
\text { Often more important } \\
\text { than graphical and } \\
\text { statistical tests in exploring } \\
\text { publication bias is } \\
\text { information that can be } \\
\text { retrieved from study } \\
\text { registries, and from } \\
\text { regulatory and other } \\
\text { agencies (e.g., gray literature). }\end{array}$ & $\begin{array}{l}\text { "Not applicable" } \\
\text { may be an } \\
\text { appropriate } \\
\text { response if the } \\
\text { assessment of } \\
\text { publication bias is } \\
\text { inappropriate (e.g., } \\
\text { less than 5-10 } \\
\text { studies) or was } \\
\text { assessed as part of } \\
\text { the tool used to } \\
\text { evaluate the body } \\
\text { of the evidence } \\
\text { (item 8). }\end{array}$ & None. & $\begin{array}{l}\text { Reword: The potential for } \\
\text { publication bias should have } \\
\text { been considered in the review, } \\
\text { using other information as } \\
\text { relevant, and graphical aids } \\
\text { and statistical tests as } \\
\text { appropriate. The limitations } \\
\text { of the statistical and } \\
\text { graphical tests should be } \\
\text { noted in the review. } \\
\text { Note: A "yes" response } \\
\text { can be used if the review } \\
\text { authors explored the data } \\
\text { and other relevant } \\
\text { information sources for } \\
\text { evidence of small study } \\
\text { or publication bias. A } \\
\text { "not applicable" response } \\
\text { should be used if } \\
\text { publication bias was } \\
\text { considered as part of } \\
\text { quality assessment of the } \\
\text { body of evidence in item } 8 .\end{array}$ & None. \\
\hline $\begin{array}{l}\text { 11. Was the conflict } \\
\text { of interest stated? }\end{array}$ & $\begin{array}{l}\text { Potential sources of } \\
\text { support should be } \\
\text { clearly acknowledged in } \\
\text { both the systematic } \\
\text { review and the included } \\
\text { studies. } \\
\text { Note: To get a "yes," } \\
\text { must indicate source } \\
\text { of funding or support } \\
\text { for the systematic } \\
\text { review AND for each } \\
\text { of the included studies. }\end{array}$ & $\begin{array}{l}\text { The phrase "conflict of } \\
\text { interest" is unclear. This } \\
\text { likely refers to whether } \\
\text { there is a disclosure of } \\
\text { conflicts, but it is unclear } \\
\text { whether this refers to } \\
\text { individual authors of the } \\
\text { review and/or included } \\
\text { studies or to the funder } \\
\text { of the review and/or } \\
\text { included studies. }\end{array}$ & $\begin{array}{l}\text { The instructions are not } \\
\text { congruent with the item. } \\
\text { "Sources of support" could } \\
\text { refer to funding for the } \\
\text { review, financial support } \\
\text { for the review authors, or } \\
\text { funding of the included } \\
\text { studies. Conflict of interest } \\
\text { includes other interests } \\
\text { that may interfere with the } \\
\text { authors' objectivity, such as } \\
\text { personal financial interests. }\end{array}$ & $\begin{array}{l}\text { "Not applicable" is } \\
\text { not an appropriate } \\
\text { response. }\end{array}$ & $\begin{array}{l}\text { Reword: Were } \\
\text { conflicts of interest } \\
\text { disclosed for all of } \\
\text { the review authors } \\
\text { and was the } \\
\text { funding source of } \\
\text { the review and of } \\
\text { each study within } \\
\text { the review } \\
\text { reported? }\end{array}$ & $\begin{array}{l}\text { Reword: Disclosures of } \\
\text { relevant interests should be } \\
\text { provided for all review } \\
\text { authors and the source of } \\
\text { funding for the review } \\
\text { and for each study } \\
\text { included in the review } \\
\text { should be reported. } \\
\text { Note: "Yes" is indicated if } \\
\text { disclosures of interest are } \\
\text { provided for all review } \\
\text { authors, the funding for } \\
\text { the review is provided } \\
\text { and is not likely to be a } \\
\text { source of bias to the } \\
\text { review's conclusions, } \\
\text { and the funding for all } \\
\text { included studies is } \\
\text { indicated (or if not } \\
\text { reported in the } \\
\text { individual studies } \\
\text { then this is indicated). }\end{array}$ & $\begin{array}{l}\text { Remove the } \\
\text { "not applicable" } \\
\text { response. }\end{array}$ \\
\hline
\end{tabular}


Table 1 Concerns regarding AMSTAR items, instructions, responses, and suggested revisions (Continued)

\begin{tabular}{|c|c|c|c|c|c|c|c|}
\hline 12. Proposed new Item & Not applicable & Not applicable & Not applicable & Not applicable & $\begin{array}{l}\text { Were relevant } \\
\text { subgroups } \\
\text { considered in } \\
\text { the review process, } \\
\text { analysis, and conclusions? }\end{array}$ & $\begin{array}{l}\text { Relevant population } \\
\text { subgroups and } \\
\text { characteristics should } \\
\text { be considered in the } \\
\text { scope and in the key } \\
\text { questions for the review, } \\
\text { and in searching, data } \\
\text { extraction and analysis } \\
\text { and in the review's } \\
\text { conclusions. } \\
\text { Note: "Yes" is indicated } \\
\text { if the main relevant } \\
\text { subpopulations and } \\
\text { characteristics were } \\
\text { considered throughout } \\
\text { the review process. }\end{array}$ & $\begin{array}{l}\text { Yes, no, } \\
\text { cannot answer }\end{array}$ \\
\hline
\end{tabular}

attems, instructions, and notes listed on AMSTAR's website (http://amstar.ca/Amstar_Checklist.php) as of June 10, 2015 
Some AMSTAR items and their instructions are unclear and need to be revised (Table 1). For example, item 4 regarding the "status of publication" might refer to either the inclusion or exclusion of gray literature. The instructions suggest that gray literature should be included; however, its relevance is closely related to the review question and may not always be necessary. In AMSTAR [1], foreign language publications are considered gray literature; however, this is not consistent with commonly used definitions [38].

The response options (yes, no, cannot answer, not applicable) are problematic [9, 39-43]. For example, "cannot answer" can be difficult to interpret and distinguish from "no" when no information is provided. A common approach to quality assessment is to assume that if the authors did not report a step, then it did not happen; thus, "no" would be the appropriate response. The instructions, however, suggest that "cannot answer" should be used when the item is "relevant but not described," which means a "no" response would rarely be used as authors seldom report explicitly that they did not do something. In addition, "not applicable" is only appropriate to two items (items 9 and 10) when these items are not possible or appropriate; all other items should always be addressed.

The guidance for scoring individual items and for obtaining a total score is unclear. In AMSTAR [1], if all criterion are met for an individual item (i.e., "yes"), it receives a score of " 1 " and the sum of all "yes" responses indicates the total score out of 11 . Systematic reviews, however, often partially meet the item's criteria such as listing the search databases and dates but, perhaps due to word limitations of the journal, do not provide the search strategies or keywords. To address the issue of evaluating multiple constructs within a single AMSTAR item, investigators have modified its scoring to allow points for partially fulfilled items [7, 9, 34, 35, 39]. Kung and colleagues developed R-AMSTAR [44], subdividing each item into four components with a score ranging from 11 to 44, where higher scores indicate better methodological quality. R-AMSTAR has been used by a number of investigators [5, 45-50], and a comparison to AMSTAR concluded that R-AMSTAR provided greater guidance for each item and is more reliable and useful [51].

In addition, AMSTAR provides no guidance on how to combine individual item scores from multiple assessors other than stating that consensus should be reached for each item. We have averaged AMSTAR scores across assessors to encompass each independent evaluation [52]. Other investigators have used similar approaches such as averaging scores between two assessors when discordant by one or two points and involving a third assessor when scores differed by three or more points $[53,54]$.
AMSTAR was deliberately developed without guidance on how to translate the total score into categorical ratings for the overall assessment of the systematic review's quality (e.g., good, fair, poor) [1, 55]. Various thresholds have been used by investigators to define categories for quality (e.g., 0-4 vs. 0-3 for poor quality), making it difficult to compare assessments across reviews. AMSTAR was also designed under the assumption that each item is of equal weight when considering the systematic review's overall quality [2]. Other investigators have dealt with this issue by assigning different weights to items they consider more important [53, 56-58]. For example, Jacobs and colleagues rated systematic reviews as high quality if items $3,6,7$, and 8 were met regardless of the total score [57]. An additional problem with the current scoring method is the equivalence of "not applicable," "no," and "cannot answer" (all scored as zero) because an item rated as "not applicable" should not be taken into account in the total score. Clearer guidance about calculating a total score is needed along with an acknowledgement of the limitations of scoring across all items should users of AMSTAR choose to calculate a total score. We believe that obtaining a total score should be avoided as it has been shown to be problematic [59].

\section{Conclusion}

AMSTAR is a useful tool for assessing the quality of systematic reviews; however, some modifications would improve its usability, reliability, and validity. The issues discussed in this commentary are not limited to our own experiences but are shared across many investigators who have used this tool. We have provided suggestions for improving AMSTAR; however, any revised tool needs to be empirically tested for reliability and validity, and undoubtedly, additional refinements will be needed. We look forward to further dialog on AMSTAR and to subsequent revisions and evaluations.

\section{Abbreviation}

AMSTAR: A Measurement Tool to Assess Systematic Reviews.

\section{Competing interests}

B.U. Burda, H.K. Holmer, and S.L. Norris used and published results of AMSTAR in the assessment of systematic review quality. S.L. Norris is an active member of the GRADE Working Group. The authors have no other conflicts of interest to declare.

\section{Authors' contributions}

$\mathrm{BUB}, \mathrm{HKH}$, and SLN conceived the design of the study, collected, analyzed, and interpreted the data, and drafted, reviewed, and approved the manuscript.

\section{Acknowledgements}

The authors thank Carrie D. Patnode, Ph.D. for reviewing the draft manuscript and Lauren A. Ogden, B.A. and Keshia D. Bigler, B.S. for the administrative support. 


\section{Funding}

This manuscript was the result of work performed for the Agency for Healthcare Research and Quality under grant HS018500-01 (S. L. Norris). The funder played no role in drafting this manuscript.

\section{Author details}

'Kaiser Permanente Center for Health Research, 3800 N. Interstate Ave, Portland, OR 97227, USA. ²Oregon Health and Science University, 3181 SW Sam Jackson Park Road, Portland, OR 97239, USA. ${ }^{3}$ World Health Organization, Av. Appia 20, CH-1211, Geneva 27, Switzerland.

\section{Received: 15 October 2015 Accepted: 5 April 2016} Published online: 12 April 2016

\section{References}

1. Shea BJ, Grimshaw JM, Wells GA, Boers M, Andersson N, Hamel C, et al. Development of AMSTAR: a measurement tool to assess the methodological quality of systematic reviews. BMC Med Res Methodol. 2007;7:10.

2. Shea BJ, Hamel C, Wells GA, Bouter LM, Kristjansson E, Grimshaw J, et al. AMSTAR is a reliable and valid measurement tool to assess the methodological quality of systematic reviews. J Clin Epidemiol. 2009;62(10): 1013-20. http://dx.doi.org/10.1016/j.jclinepi.2008.10.009.

3. Shea BJ, Bouter LM, Peterson J, Boers M, Andersson N, Ortiz Z, et al. External validation of a measurement tool to assess systematic reviews (AMSTAR). PLoS ONE. 2007;2(12), e1350.

4. Chambrone L, Faggion Jr CM, Pannuti CM, Chambrone LA. Evidence-based periodontal plastic surgery: an assessment of quality of systematic reviews in the treatment of recession-type defects. J Clin Periodontol. 2010;37(12): 1110-8. http://dx.doi.org/10.1111/j.1600-051X.2010.01634.x.

5. Klimo Jr P, Thompson CJ, Ragel BT, Boop FA. Methodology and reporting of meta-analyses in the neurosurgical literature. J Neurosurg. 2014;120(4): 796-810. http://dx.doi.org/10.3171/2013.11.JNS13195.

6. Nicolau I, Ling D, Tian L, Lienhardt C, Pai M. Methodological and reporting quality of systematic reviews on tuberculosis. Int J Tuberc Lung Dis. 2013; 17(9):1160-9. http://dx.doi.org/10.5588/ijtld.13.0050

7. Aziz T, Compton S, Nassar U, Matthews D, Ansari K, Flores-Mir C. Methodological quality and descriptive characteristics of prosthodonticrelated systematic reviews. J Oral Rehabil. 2013;40(4):263-78. http://dx.doi.org/10.1111/joor.12028.

8. Elangovan S, Avila-Ortiz G, Johnson GK, Karimbux N, Allareddy V. Quality assessment of systematic reviews on periodontal regeneration in humans. J Periodontol. 2013;84(2):176-85. http://dx.doi.org/10.1902/jop.2012.120021.

9. Fleming PS, Koletsi D, Seehra J, Pandis N. Systematic reviews published in higher impact clinical journals were of higher quality. J Clin Epidemiol. 2014; 67(7):754-9. http://dx.doi.org/10.1016/j.jclinepi.2014.01.002.

10. Kamioka H, Tsutani K, Okuizumi H, Mutoh Y, Ohta M, Handa S, et al. Effectiveness of aquatic exercise and balneotherapy: a summary of systematic reviews based on randomized controlled trials of water immersion therapies. J Epidemiol. 2010;20(1):2-12.

11. Lang LA, Teich ST. A critical appraisal of the systematic review process: systematic reviews of zirconia single crowns. J Prosthet Dent. 2014;111(6): 476-84. http://dx.doi.org/10.1016/j.prosdent.2013.10.007.

12. Macedo $C R$, Riera $R$, Torloni MR. Methodological quality of systematic reviews and clinical trials on women's health published in a Brazilian evidence-based health journal. Clinics. 2013;68(4):563-7. http://dx.doi.org/10. 6061/clinics/2013(04)20.

13. Remschmidt C, Wichmann $\mathrm{O}$, Harder T. Methodological quality of systematic reviews on influenza vaccination. Vaccine. 2014;32(15):1678-84 http://dx.doi.org/10.1016/j.vaccine.2014.01.060.

14. Kumar A, Galeb S, Djulbegovic B. Treatment of patients with multiple myeloma: an overview of systematic reviews. Acta Haematol. 2011;125(1-2): 8-22. http://dx.doi.org/10.1159/000318880

15. Prior M, Guerin M, Grimmer-Somers K. The effectiveness of clinical guideline implementation strategies - a synthesis of systematic review findings. J Eval Clin Pract. 2008;14(5):888-97. http://dx.doi.org/10.1111/j. 1365-2753.2008.01014.x

16. Seo HJ, Kim KU. Quality assessment of systematic reviews or meta-analyses of nursing interventions conducted by Korean reviewers. BMC Med Res Methodol. 2012;12:129. http://dx.doi.org/10.1186/1471-2288-12-129.
17. Sequeira-Byron P, Fedorowicz Z, Jagannath VA, Sharif MO. An AMSTAR assessment of the methodological quality of systematic reviews of oral healthcare interventions published in the Journal of Applied Oral Science (JAOS). J Appl Oral Sci. 2011;19(5):440-7.

18. Andersen JH, Fallentin N, Thomsen JF, Mikkelsen S. Risk factors for neck and upper extremity disorders among computers users and the effect of interventions: an overview of systematic reviews. PLoS ONE. 2011;6(5): e19691. http://dx.doi.org/10.1371/journal.pone.0019691.

19. Berkhof $M$, van Rijssen $H J$, Schellart AJ, Anema JR, van der Beek AJ. Effective training strategies for teaching communication skills to physicians: an overview of systematic reviews. Patient Educ Couns. 2011;84(2):152-62. http://dx.doi.org/10.1016/j.pec.2010.06.010.

20. Johnson BT, MacDonald HV, Bruneau Jr ML, Goldsby TU, Brown JC, HuedoMedina TB, et al. Methodological quality of meta-analyses on the blood pressure response to exercise: a review. J Hypertens. 2014;32(4):706-23. http://dx.doi.org/10.1097/HJH.0000000000000097.

21. Kelley GA, Kelley KS. Effects of exercise in the treatment of overweight and obese children and adolescents: a systematic review of meta-analyses. J Obes. 2013:2013:783103. http://dx.doi.org/10.1155/2013/783103.

22. Kelley GA, Kelley KS. Effects of exercise on depressive symptoms in adults with arthritis and other rheumatic disease: a systematic review of meta-analyses. BMC Musculoskelet Disord. 2014;15:121. http://dx.doi.org/ 10.1186/1471-2474-15-121.

23. Massougbodji J, Le Bodo Y, Fratu R, De Wals P. Reviews examining sugar-sweetened beverages and body weight: correlates of their quality and conclusions. Am J Clin Nutr. 2014;99(5):1096-104. http://dx.doi.org/ 10.3945/ajen.113.063776.

24. Nuckols TK, Anderson L, Popescu I, Diamant AL, Doyle B, Di Capua P, et al Opioid prescribing: a systematic review and critical appraisal of guidelines for chronic pain. Ann Intern Med. 2014;160(1):38-47. http://dx.doi.org/10. 7326/0003-4819-160-1-201401070-00732.

25. Panic N, Leoncini E, de Belvis G, Ricciardi W, Boccia S. Evaluation of the endorsement of the preferred reporting items for systematic reviews and meta-analysis (PRISMA) statement on the quality of published systematic review and meta-analyses. PLoS ONE. 2013;8(12):e83138. http://dx.doi.org/ 10.1371/journal.pone.0083138.

26. Pieper D, Mathes T, Eikermann M. Can AMSTAR also be applied to systematic reviews of non-randomized studies? BMC Res Notes. 2014;7:609. http://dx.doi.org/10.1186/1756-0500-7-609.

27. Saokaew S, Oderda GM. Quality assessment of the methods used in published opioid conversion reviews. J Pain Palliat Care Pharmacother. 2012 26(4):341-7. http://dx.doi.org/10.3109/15360288.2012.734904.

28. Sardanelli F, Bashir H, Berzaczy D, Cannella G, Espeland A, Flor N, et al. The role of imaging specialists as authors of systematic reviews on diagnostic and interventional imaging and its impact on scientific quality: report from the EuroAIM Evidence-based Radiology Working Group. Radiology. 2014; 272(2):533-40. http://dx.doi.org/10.1148/radiol.14131730.

29. Walton DM, Carroll LJ, Kasch H, Sterling M, Verhagen AP, Macdermid JC, et al. An overview of systematic reviews on prognostic factors in neck pain: results from the International Collaboration on Neck Pain (ICON) project. Open Orthop J. 2013;7:494-505. http://dx.doi.org/10.2174/1874325001307010494.

30. Wiysonge CS, Ngcobo NJ, Jeena PM, Madhi SA, Schoub BD, Hawkridge A, et al. Advances in childhood immunisation in South Africa: where to now? Programme managers' views and evidence from systematic reviews. BMC Public Health. 2012;12:578. http://dx.doi.org/10.1186/1471-2458-12-578.

31. Higgins JPT, Green S. Cochrane handbook of systematic reviews of interventions. West Sussex: The Cochrane Collaboration; 2008.

32. Moher D, Liberati A, Tetzlaff J, Altman DG, Group P. Preferred reporting items for systematic reviews and meta-analyses: the PRISMA statement. J Clin Epidemiol. 2009;62(10):1006-12. doi:10.1016/j.jclinepi.2009.06.005.

33. Whiting P, Savovic J, Higgins JP, Caldwell DM, Reeves BC, Shea B, et al. ROBIS: a new tool to assess risk of bias in systematic reviews was developed. J Clin Epidemiol. 2016;69:225-34. doi:10.1016/j.jclinepi.2015.06.005.

34. Papageorgiou SN, Papadopoulos MA, Athanasiou AE. Evaluation of methodology and quality characteristics of systematic reviews in orthodontics. Orthod Craniofac Res. 2011;14(3):116-37. http://dx.doi.org/ 10.1111/j.1601-6343.2011.01522.x.

35. Papageorgiou SN, Papadopoulos MA, Athanasiou AE. Reporting characteristics of meta-analyses in orthodontics: methodological assessment and statistical recommendations. Eur J Orthod. 2014;36(1): 74-85. http://dx.doi.org/10.1093/ejo/cjt008. 
36. Brito JP, Tsapas A, Griebeler ML, Wang Z, Prutsky GJ, Domecq JP, et al. Systematic reviews supporting practice guideline recommendations lack protection against bias. J Clin Epidemiol. 2013;66(6):633-8. http://dx.doi. org/10.1016/j.jclinepi.2013.01.008.

37. Berkman ND, Lohr KN, Morgan LC, Kuo TM, Morton SC. Interrater reliability of grading strength of evidence varies with the complexity of the evidence in systematic reviews. J Clin Epidemiol. 2013;66(10):1105-17. doi:10.1016/j. jclinepi.2013.06.002. e1.

38. Institute of Medicine. Finding what works in health care: standards for systematic reviews. Washington, D.C.: National Academies Press; 2011.

39. Faggion Jr CM, Listl S, Giannakopoulos NN. The methodological quality of systematic reviews of animal studies in dentistry. Vet J. 2012;192(2):140-7. http://dx.doi.org/10.1016/j.tvjl.2011.08.006.

40. Kang D, Wu Y, Hu D, Hong Q, Wang J, Zhang X. Reliability and external validity of AMSTAR in assessing quality of TCM systematic reviews. Evid Based Complement Alternat Med. 2012;2012:732195. http://dx.doi.org/10. 1155/2012/732195

41. Rookmoneea M, Dennis L, Brealey S, Rangan A, White B, McDaid C, et al. The effectiveness of interventions in the management of patients with primary frozen shoulder. J Bone Joint Surg (Br). 2010;92(9):1267-72. http://dx.doi.org/10.1302/0301-620X.92B9.24282.

42. de Bot CM, Moed H, Berger MY, Roder E, van Wijk RG, van der Wouden JC. Sublingual immunotherapy in children with allergic rhinitis: quality of systematic reviews. Pediatr Allergy Immunol. 2011;22(6):548-58. http://dx. doi.org/10.1111/j.1399-3038.2011.01165.x.

43. Miyahara M. Meta review of systematic and meta analytic reviews on movement differences, effect of movement based interventions, and the underlying neural mechanisms in autism spectrum disorder. Front Integr Neurosci. 2013;7:16. http://dx.doi.org/10.3389/fnint.2013.00016.

44. Kung J, Chiappelli F, Cajulis OO, Avezova R, Kossan G, Chew L, et al. From systematic reviews to clinical recommendations for evidence-based health care: validation of Revised Assessment of Multiple Systematic Reviews (R-AMSTAR) for grading of clinical relevance. Open Dent J. 2010;4 84-91. http://dx.doi.org/10.2174/1874210601004020084.

45. Faggion Jr CM, Giannakopoulos NN. Critical appraisal of systematic reviews on the effect of a history of periodontitis on dental implant loss. J Clin Periodontol. 2013;40(5):542-52. http://dx.doi.org/10.1111/jcpe.12096.

46. Deckert S, Kopkow C, Schmitt J. Nonallergic comorbidities of atopic eczema: an overview of systematic reviews. Allergy. 2014;69(1):37-45. http://dx.doi. org/10.1111/all.12246.

47. Kitsiou S, Pare G, Jaana M. Systematic reviews and meta-analyses of home telemonitoring interventions for patients with chronic diseases: a critical assessment of their methodological quality. J Med Internet Res. 2013;15(7): e150. http://dx.doi.org/10.2196/jmir.2770.

48. Ramchandani M, Siddiqui M, Kanwar R, Lakha M, Phi L, Giacomelli L, et al. Proteomic signature of periodontal disease in pregnancy: predictive validity for adverse outcomes. Bioinformation. 2010;5(7):300-3.

49. Schmitter M, Sterzenbach G, Faggion Jr CM, Krastl G. A flood tide of systematic reviews on endodontic posts: methodological assessment using of R-AMSTAR. Clin Oral Investig. 2013;17(5):1287-94. http://dx.doi.org/10. 1007/s00784-013-0945-z.

50. Wells C, Kolt GS, Marshall P, Hill B, Bialocerkowski A. Effectiveness of Pilates exercise in treating people with chronic low back pain: a systematic review of systematic reviews. BMC Med Res Methodol. 2013;13:7. http://dx.doi.org/ 10.1186/1471-2288-13-7.

51. Popovich I, Windsor B, Jordan V, Showell M, Shea B, Farquhar CM. Methodological quality of systematic reviews in subfertility: a comparison of two different approaches. PLoS ONE. 2012;7(12):e50403. http://dx.doi.org/10. 1371/journal.pone.0050403.

52. Burda BU, Norris SL, Holmer HK, Ogden LA, Smith ME. Quality varies across clinical practice guidelines for mammography screening in women aged 40-49 years as assessed by AGREE and AMSTAR instruments. J Clin Epidemiol. 2011;64(9):968-76. http://dx.doi.org/10. 1016/j.jclinepi.2010.12.005

53. Weed DL, Althuis MD, Mink PJ. Quality of reviews on sugar-sweetened beverages and health outcomes: a systematic review. Am J Clin Nutr. 2011: 94(5):1340-7. http://dx.doi.org/10.3945/ajcn.111.015875.

54. Monasta L, Batty GD, Cattaneo A, Lutje V, Ronfani L, Van Lenthe FJ, et al. Early-life determinants of overweight and obesity: a review of systematic reviews. Obes Rev. 2010;11(10):695-708. http://dx.doi.org/10. 1111/j.1467-789X.2010.00735.x.
55. Needleman I, Clarkson J, Worthington H. A practitioner's guide to developing critical appraisal skills: reviews of research. J Am Dent Assoc 2013;144(5):527-30.

56. List T, Axelsson S. Management of TMD: evidence from systematic reviews and meta-analyses. J Oral Rehabil. 2010;37(6):430-51. http://dx.doi.org/10. 1111/j.1365-2842.2010.02089.x.

57. Jacobs WC, Rubinstein SM, Willems PC, Moojen WA, Pellise F, Oner CF, et al. The evidence on surgical interventions for low back disorders, an overview of systematic reviews. Eur Spine J. 2013;22(9):1936-49. http://dx.doi.org/10. 1007/s00586-013-2823-4

58. Jaspers MW, Smeulers M, Vermeulen H, Peute LW. Effects of clinical decision-support systems on practitioner performance and patient outcomes: a synthesis of high-quality systematic review findings. J Am Med Inform Assoc. 2011;18(3):327-34. http://dx.doi.org/10.1136/ amiajnl-2011-000094.

59. Juni $P$, Witschi $A$, Bloch $R$, Egger $M$. The hazards of scoring the quality of clinical trials for meta-analysis. JAMA. 1999;282(11):1054-60.

60. Guyatt GH, Oxman AD, Vist GE, Kunz R, Falck-Ytter Y, Alonso-Coello P, et al. GRADE: an emerging consensus on rating quality of evidence and strength of recommendations. BMJ. 2008;336(7650):924-6. http://dx.doi. org/10.1136/bmj.39489.470347.AD.

61. Harris RP, Helfand M, Woolf SH, Lohr KN, Mulrow CD, Teutsch SM, et al. Current methods of the US Preventive Services Task Force: a review of the process. Am J Prev Med. 2001;20(3 Suppl):21-35.

\section{Submit your next manuscript to BioMed Central and we will help you at every step:}

- We accept pre-submission inquiries

- Our selector tool helps you to find the most relevant journal

- We provide round the clock customer support

- Convenient online submission

- Thorough peer review

- Inclusion in PubMed and all major indexing services

- Maximum visibility for your research

Submit your manuscript at www.biomedcentral.com/submit
Biomed Central 